\title{
COMBATING CORRUPTION BASED ON INTERNATIONAL RULES
}

\begin{abstract}
Maskun*
Abstract

Corruption is a universal problem that is taking place all over the world, either in developed countries or developing or under developing countries. It is caused by some issues such as poorly designed economic policies, low levels of education, underdeveloped civil society, and the weak accountability of public institution. Those causes of corruption can be separated in some different types of corruption. The types are bureaucratic corruption, political corruption, grand corruption, and common corruption. In terms of tackling some problems of corruption, there are so many things to do including international law commitment. Some international law commitment can be seen like OAS Convention, OECD's anti-bribery Convention, the UN Convention against Transnational Organized Crime, and the United Nation Convention against Corruption (UNCAC). Those laws must be analyzed not only in context of substantive of those laws but also how they are implemented in state practices.
\end{abstract}

Keywords: International Rules, Combat to Corruption

\begin{abstract}
Abstrak
Korupsi adalah masalah universal yang berlangsung di seluruh dunia, baik di negara maju atau negara berkembang atau di negara-negara yang kurang berkembang. Hal ini disebabkan oleh beberapa masalah seperti kebijakan ekonomi yang dirancang secara buruk, rendahnya tingkat pendidikan, masyarakat sipil terbelakang, dan akuntabilitas yang lemah dari lembaga publik. Penyebab korupsi ini dapat dipisahkan dalam beberapa jenis korupsi. Jenis korupsi adalah korupsi birokrasi, korupsi politik, korupsi besar, dan korupsi umum. Dalam hal menangani beberapa masalah korupsi, ada begitu banyak hal yang harus dilakukan termasuk komitmen hukum internasional. Beberapa komitmen hukum internasional dapat dilihat seperti Konvensi OAS, Konvensi OECD Anti-Penyuapan, Konvensi PBB Menentang Kejahatan Transnasional Terorganisir, dan Konvensi Perserikatan Bangsa Anti Korupsi (UNCAC). Hukum tersebut harus dianalisis tidak hanya dalam konteks substantif hukum-hukum tetapi juga bagaimana mereka diimplementasikan dalam praktek negara.
\end{abstract}

Kata Kunci: Aturan Hukum Internasional, Pemberantasan Korupsi

\section{Introduction}

Corruption has become mankind enemy and even had transformed into a fearful "endemic disease". The endemic disease means that it becomes a universal problem that is taking place all over the world, either in developed countries or developing or under developing countries. ${ }^{1}$ There is almost no empty space in this world where someone did not act corruption, especially in the third world countries (developing and least developing countries). Many practices once part of business and politics as-usual are now regarded

* Lecturer of International Law Department, Faculty of Law, Hasanuddin University, (SH - UNHAS, Makassar 1998), (LLM -UNSW, Sdyney 2004), (PhD Candidate - by Research, Postgraduate Hasanuddin University).

${ }^{1}$ Gerasimova Ksenia,"Can Corruption and Economic Crime be controlled in Developing Countries and if so, is it cost-effective?", Journal of Financial Crime, ' Vol. 15, No.2, 2008, p. 223. 
as corrupt. Some problems can cause it such as poorly designed economic policies, low levels of education, under-developed civil society, and the weak accountability of public institution. Those corruption causes then can be ranked as the most significant obstacles to create good governance, development, and commerce all over the world. ${ }^{2}$

As the enemy of international community, corruption has to be eradicated systematically and structurally. It means that in international level, all countries around the world should have the same commitment to combat corruption either in forms of international regulation or in forms of international cooperation amongst states. Some relevant international regulations are OAS Convention, OECD's anti-bribery The UN Convention against Transnational Organized Crime, ${ }^{3}$ and United Nation Convention against Corruption (UNCAC). In forms of international commitment in general, all countries have agreed to celebrate December 9th as "International Anti-Corruption Day". The fact that such a symbolic day exists reflects the international community's increased recognition of the importance of anticorruption measures. ${ }^{4}$

At national level, furthermore, every state should have strong commitment to ratify some international regulations to be applied as their national law. It means that every state applies those international regulations to be part of its fundamental principles of legal system. For example Indonesia, It has ratified UNCAC and legislated it in the Law Number 7/2006 concerning Ratification of UNCAC 2003. ${ }^{5}$ The Law determines to make reservation to the article $66(2)^{6}$ UNCAC concerning dispute settlement. The article of dispute settlement shall be provided in both languages Indonesia and English and is a part of the Law Number 7/2006.

At the political level, corruption has risen also in recent years in national agendas because of its role in political developments. At one point the heads of government themselves of Indonesia, the Philippines, and Thailand were in the dock on corruption-related charges. Peaceful populist protest forced the Philippine president, Joseph Estrada, to step down in January 2001. In July 2001 Indonesia's parliament removed President Abdurrahman Wahid from office partly because of corruption allegations. Thaksin Shinawatra, prime minister of Thailand, was indicted by the National Counter-Corruption Commission but was eventually acquitted in a controversial decision by the country's Constitutional Court. In 2002 the convictions of two sons of President Kim Dae-Jung of the Republic of Korea on corruption charges

\footnotetext{
${ }^{2}$ Sabine Konrad, "International Law and the Fight against Corruption”, ASIL Proceedings, 2008, p. 203.

${ }^{3}$ David Hess, “Catalyzing Corporate Commitment to Combating Corruption', Journal of Business Ethics, Vol. 88, 2009, p. 781.

${ }^{4}$ Jan Wouters, et.al., "The International Legal Framework Against Corruption: Achievements And Challenges", Melbourne Journal of International Law, Vol. 14 Issue 1, 2013, p. 205.

${ }^{5}$ The Law Number 7/2006 concerning Ratification of UNCAC 2003, Art. (1) and (2).

${ }^{6}$ Article 66 (2) UNCAC states "Any dispute between two or more States Parties concerning the interpretation or application of this Convention that cannot be settled through negotiation within a reasonable time shall, at the request of one of those States Parties, be submitted to arbitration. If, six months after the date of the request for arbitration, those States Parties are unable to agree on the organization of the arbitration, any one of those States Parties may refer the dispute to the International Court of Justice by request in accordance with the Statute of the Court".
} 
tarnished the president's achievements. ${ }^{7}$

Based on some overview as explained above, this paper focuses in identifying some international rules that address fighting against corruption in broad sense. These laws embody in some conventions and show their commitment to eradicate or diminish (at least) corruption in all countries around the world.

\section{Discussion and Analysis}

\section{A. Definition of Corruption}

To define what corruption means, it is not difficult task. There is enormous literature to define it. According to $\mathrm{McCullen}^{8}$, a general definition of corruption would be:

"...an individual or a group is guilty of corruption if they accept money or money's worth for doing something that is under a duty to do anyway, that he is under a duty to do or to exercise a legitimate discretion for improper reason".

UNCAC on the other hand does not define directly what corruption is. It classifies some activities of person or group corruption as corruption, as followings: ${ }^{9}$

"(a) "Public official" shall mean:

(i) any person holding a legislative, executive, administrative or judicial office of a State Party, whether appointed or elected, whether permanent or temporary, whether paid or unpaid, irrespective of that person's seniority;

(ii) any other person who performs a public function, including for a public agency or public enterprise, or provides a public service, as defined in the domestic law of the State Party and as applied in the pertinent area of law of that State Party;

(iii) any other person defined as a "public official" in the domestic law of a State Party. However, for the purpose of some specific measures contained in chapter II of this Convention, "public official" may mean any person who performs a public function or provides a public service as defined in the domestic law of the State Party and as applied in the pertinent area of law of that State Party;

(b) "Foreign public official" shall mean any person holding a legislative, executive, administrative or judicial office of a foreign country, whether appointed or elected; and any person exercising a public function for a foreign country, including for a public agency or public enterprise;

(c) "Official of a public international organization" shall mean an international civil servant or any person who is authorized by such an organization to

\footnotetext{
${ }^{7}$ Vinay Bhargava and Emil Bolongaita, (2004). Challenging Corruption in Asia: Case Studies and a Framework for Action, Wshington D.C: the World Bank, pp. 1-2.

${ }^{8}$ McCullen cited in A. Seyf, (2000), Corruption and Development, Staffordshire University: Division of Economics Working Paper N2000., p.7.

${ }^{9}$ UNCAC 2003, Art. 2. (a),(b),(c).
} 


\section{act on behalf of that organization".}

Based on article 2 as mentioned above, it defines several important terms recurring throughout the Convention. National legislation may include broader definitions but should, as a minimum, cover what is required according to the Convention. States parties are not obliged to incorporate into their national legislation the definitions as they stand in the Convention. All of the terms defined in article 2 relate to substantive provisions and legislative or other requirements under the Convention. They require therefore thorough consideration to ensure that the entire range of persons defined by article 2 , for example, as "public officials" is adequately covered under national legislation and measures. ${ }^{10}$

Related to UNCAC's definition, Transparency International ${ }^{11}$ defines corruption as 'misuse of public power for private gain'. ${ }^{12}$ World Bank itself recognizes corruption as a symptom of other, deeper-seated factors such as poorly designed economic policies, low levels of education, under-developed civil society, and the weak accountability of public institution. ${ }^{13}$

Amongst definition of corruption as stated above draw some different approach to define corruption. However, there is no inconsistency definition between them. They support one to another in order to show the scope of corruption.

\section{B. Types of Corruption}

Basically, there are numerous variations on the forms of corruption. They can be recognized based on corruption typologies. Those types are:

a. Bribery ${ }^{14}$;

It would be stated as bribery when committed intentionally, the promise, offering or giving to for the official himself or herself or another person or entity, or to a foreign public official or an official of a public international organization, directly or indirectly, of an undue advantage, for the official himself or herself or another person or entity, in order that the official act or refrain from acting in the exercise of his or her official duties, in order to obtain or retain business or other undue advantage in relation to the conduct of international business.

It is included bribery in private sectors ${ }^{15}$.

${ }^{10}$ UNODC, 'Legislative guide for the implementation of the United Nations Convention against Corruption, 2nd Revised Edition 2012' <https://www.unodc.org/documents/treaties/UNCAC/Publications/ LegislativeGuide/UNCAC_Legislative_Guide_E.pdf>, accessed, 19 May 2014.

${ }^{11}$ Headquartered in Germany, TI was founded in 1993 by a group of individuals who have "shared in common the experience of having witnessed firsthand the devastating effects of cross-border corruption. TI is a politically non-partisan organization whose primary function is raising awareness about corruption on a global level." TI is organized around a national chapter system that now includes 95 countries.

${ }^{12}$ Lars Johannsen and Karin Hilmer Pedersen, "For The Common Good: Combating Corruption In New EU Member States”, Journal of Comparative Politics, Vol. 4 Issue 1, 2011, p. 92.

${ }^{13}$ World Bank, 'Helping Countries Combat Corruption: the Role of the World Bank' Poverty Reduction and Economic Management, <wwwl.worldbank.org/publicsector/anticorrupt/orruptn/corid.html>.

${ }^{14}$ UNCAC 2003, Art. (15) and (16).

${ }^{15}$ UNCAC 2003, Art. (21). 
b. Embezzlement, misappropriation or other diversion of property by a public official ${ }^{16}$;

It is stated as Embezzlement, misappropriation or other diversion of property by a public official when committed intentionally, the embezzlement, misappropriation or other diversion by a public official for his or her benefit or for the benefit of another person or entity, of any property, public or private funds or securities or any other thing of value entrusted to the public official by virtue of his or her position.

It is included embezzlement of property in private sectors. ${ }^{17}$

c. Trading in Influence ${ }^{18}$;

It can be classified as a corruption when the promise, offering or giving including the solicitation or acceptance by a public official or any other person, directly or indirectly, of an undue advantage in order that the public official or the person abuse his or her real or supposed influence with a view to obtaining from an administration or public authority of the State Party an undue advantage for the original instigator of the act or for any other person;

d. Abuse of Functions ${ }^{19}$;

It is a criminal offence, when committed intentionally, the abuse of functions or position, that is, the performance of or failure to perform an act, in violation of laws, by a public official in the discharge of his or her functions, for the purpose of obtaining an undue advantage for himself or herself or for another person or entity.

e. Illicit enrichment ${ }^{20}$;

It is a criminal offence, when committed intentionally, illicit enrichment, that is, a significant increase in the assets of a public official that he or she cannot reasonably explain in relation to his or her lawful income.

\section{International Rules to Fight against Corruption}

International community has showed its big efforts to combat corruption by setting the agenda of many governments. Two global gatherings of anticorruption practitioners from country governments, international organizations, donor countries, international nongovernmental organizations, and national political leaders have gained in stature and reach. These are the International Anti-Corruption Conference (IACC) series (www.11iacc.org) and the Global Forum series (www.globalforum3.org). ${ }^{21}$

The IACC series has included a wide range of anticorruption stakeholders (governments, civil society organizations, international institutions, media, and so forth) whereas the Global Forum series has been primarily a gathering of government ministers with participation from invited experts, multilateral institutions, and leading civil society organizations. The IACC series started

\footnotetext{
${ }^{16}$ UNCAC 2003, Art. (17).

${ }^{17}$ UNCAC 2003, Art. (22).

${ }^{18}$ UNCAC 2003, Art. (18).

${ }^{19}$ UNCAC 2003, Art. (19).

${ }^{20}$ UNCAC 2003, Art. (20).

${ }^{21}$ Vinay Bhargava and Emil Bolongaita, supra.
} 
in 1983 whereas the Global Forum is of more recent origin and had its first meeting in 1999. The 11th IACC and Global Forum III were scheduled back to back in May 2003 in Seoul, Korea.

This conjunction underscored efforts at international coalition-building to foster advocacy and implementation of the anticorruption agenda. The participants included ministers, senior officials, and representatives of various state bodies representing 123 countries and various intergovernmental and nongovernmental organizations. The final declaration at the end of the forum sought to ensure that corruption will continue to be a high priority on international and national agendas. ${ }^{22}$

The big effort of international community has to be supported by all countries around the world with international cooperation to provide international law instrument. The necessity of international law instruments to fight against corruption is indeed pivotal to tackle this issue. The intention of the instruments is created to put corruption matter as the seriousness of problems. As we know, corruption has threatened the stability and security of societies, undermining the institutions and values of democracy, ethical values and justice and jeopardizing sustainable development and the rule of law.

Some international law instruments of combating corruption are: ${ }^{23}$

1. Organization of American States Inter-American Convention Against Corruption 1996 ('OAS Convention');

2. Organization for Economic Co-operation and Development Convention on Combating Bribery of Foreign Public Officials in International Business Transactions 1997 ('OECD Convention');

3. Convention drawn up on the basis of Article K.3 (2) (c) of the Treaty on European Union on the Fight Against Corruption involving Officials of the European Union Communities or Officials of Member States of the European Union 1999 ('EU Convention');

4. (Council of Europe Criminal Law Convention on Corruption 1999 ('COE Convention');

5. Southern African Development Protocol Against Corruption 2001 ('SADC Protocol');

6. African Union Convention of Preventing and Combating Corruption 2003 ('AU Convention');

7. United Nations Convention Against Corruption 2003 ('UN Convention');

8. Council of Europe Additional Protocol to the Criminal Law Convention on Corruption 2003 ('COE Protocol').

Those legal instruments as mentioned above show their position as source of international law. In terms of it, those convention actually are legally binding to article 38 (1) (a) of the International Court of Justice (ICJ) statute. ${ }^{24}$ This article is an umbrella law of source of international law. The

${ }^{22}$ Ibid.

${ }^{23}$ Indira Carr, "Corruption, Legal Solutions and Limits of Law", International Journa of Law 1 in Context, Vol. 3 No.3, 2007, pp. 230-1.

${ }^{24}$ The source of international law is custom, treaty, general principle, and opinion juris and state 
phrase 'source of law' is typically employed as a term of art describing the underlying concept or methodologies which generate legal norms. Therefore, to understand those international law instruments against corruption as mentioned previously, it is interesting to explain randomly those instruments, as follows:

1. Organization of American States Inter-American Convention Against Corruption 1996 ('OAS Convention')

The OAS Convention is the earliest anti-corruption convention with the prime objective of eradicating corruption in the performance of public functions. It focuses on some features: ${ }^{25}$

1) it creates corruption offences both in the context of mutual exchange between the offeror and the recipient and where there is no mutual exchange;

2 ) it includes corrupt activities of both public officials and foreign public officials;

3 ) it covers both passive bribery (solicitation and acceptance by a public official of a benefit in return for an act or omission) and active bribery (offering or granting of a benefit to a public official in return for the doing or not doing of an act); and

4) it creates a controversial offence of illicit enrichment.

The first corruption offence was created by this convention is bribery. The solicitation or acceptance, or the offering or granting, directly or indirectly of any article of monetary value or other benefit in exchange for any act or omission in the performance of his public functions by a governmental official or public official is made an offence.

The OAS Convention has an extra-territorial dimension and makes active bribery of a foreign public official an offence (Art. VIII). Foreign public official is not defined as such but presumably the definition of a public official referred to above will be relevant. ${ }^{26}$

The OAS Convention, as stated earlier, addresses corrupt acts that do not involve a mutual exchange. Article VI includes acts or omissions by a public official for the purpose of illicitly obtaining benefits for himself or for a third party. This will cover acts such as failure to record donations and their diversion for personal or third party use. Since gains derived from corrupt behaviour are likely to be concealed, the Convention also makes the use and concealment of property derived through corrupt acts as outlined in the Convention an offence (Art. VI (1)(d)).

An interesting but questionable offence included in the OAS Convention is the offence of illicit enrichment. This is also found in a number of other conventions and has been a source of some debate.

practices. In general international law, the process of law-making is defined only by Article 38 of the ICJ Statute. And as we have already seen, Article 38 differentiates between three processes: treaty, custom and general principles of law. However, Article 38 (1) (b) of the ICJ Statute sets out two elements which underlie a norm of customary international law: opinio juris and state practice.

${ }^{25}$ Indira Carr, op.cit, p. 233.

${ }^{26}$ Ibid. p.234. 


\section{OECD Anti-Bribery Convention ${ }^{27}$}

The Convention is substantively focused instrument those who pay bribes to public officials to win or maintain business abroad. The thirty-seven parties, which include all thirty OECD countries and seven non member states, have ratified the convention. ${ }^{28}$

The Convention considers bribery as a widespread phenomenon in international business transactions, including trade and investment, which raises serious moral and political concerns, undermines good governance and economic development, and distorts international competitive conditions. ${ }^{29}$ The bribery is furthermore deemed as a common method for companies to gain higher returns by winning contracts or concessions on more profitable terms. According to Osbourne ${ }^{30}$, the bribery is made by monopoly power, over regulation, discontent with rewards, strong kinship ties and rapid change.

Article 3 of the Convention states that member countries should criminalize the bribery of foreign public officials:

"The bribery of a foreign public official shall be punishable by effective, proportionate and dissuasive criminal penalties. The range of penalties shall be comparable to that applicable to the bribery of the Part's own public officials and shall, in the case of natural persons, include deprivation of liberty sufficient to enable effective mutual legal assistance and extradition".,31

And :

[...] monetary or other civil. Administrative or criminal penalties on any legal person involved, should be provided, taking into account the amount of the bribery and of the profits derived from the transaction obtained through the bribe. ${ }^{32}$

Apart from requiring criminalization of transnational bribery, the Convention requires parties to take "books and records" measures, such as prohibiting the establishment off-the books accounts and off-the books or inadequately identified transaction. ${ }^{33}$ It requires that sanctions be "effective, proportionate and dissuasive" and that countries establish liability for legal persons. $^{34}$

The Convention however only covers corruption to the extent it is

${ }^{27}$ Came into force on 15 February 1999 and has received ratifications or accessions from Argentina, Australia, Austria, Belgium, Brazil, Bulgaria, Canada, Chile, Czech Republic, Denmark, Estonia, Finland, France, Germany, Greece, Hungary, Iceland, Ireland, Italy, Japan, Korea, Luxembourg, Mexico, Netherlands, New Zealand, Norway, Poland, Portugal, Slovak Republic, Slovenia, Spain, Sweden, Switzerland, Turkey, the United Kingdom and the United States.

${ }^{28}$ Sabine Konrad, op.cit.

${ }^{29}$ OECD, (2011). Convention on Combating Bribery of Foreign Public Officials in International Business Transactions, OECD: OECD Publishing, p. 6.

${ }^{30}$ D. Osbourne, Corruption as Counter Culture: Attitudes to Bribery in Local and Global Society, in Rider, B.A.K. (Ed), (1997), Corruption: Enemy Within, Kluwer Law International , p. 1.

${ }^{31}$ The OECD Anti-bribery Convention, Art. 3 (1).

32 The OECD Anti-bribery Convention, Art. 3 (4).

${ }^{33}$ Robert Leventhal, "International Law and the Fight against Corruption", ASIL Proceedings, 2008, p. 204.

34 Ibid. 
related to business transactions. Moreover, it only covers active corruption, which is the promise, offering or giving of a bribe. This seems to mirror early discussions in the UN, where developing countries focused on the corrupting effect of the activities of Western corporations. ${ }^{35}$

Article 9 of the OECD Convention also determines cross-border legal assistance in dealing with bribery cases. Paragraph XIII of the 2009 Recommendation for Further Combating Foreign Bribery also addresses MLA and, inter alia, recommends that Parties consider ways to facilitate MLA in foreign bribery cases, both between each other and with non-Parties. ${ }^{36}$

The legal assistance mechanisms including police-to-police assistance, mutual legal assistance treaties (MLATs), multilateral treaties, letters rogatory, and executive agreements. MLAT requests to and from other countries are processed by the DOJ, Criminal Division, Office of International Affairs (OIA).$^{37}$ Some MLAT's can be seen in Among the BRIC countries, MLATs exist with Brazil (2001) and surprisingly, with the Russian Federation, as of 2002. Another example is a recent memorandum of understanding between Indonesia's Corruption Eradication Commission (KPK) and the U.S. Federal Bureau of Investigation. ${ }^{38}$

\section{The UN Convention against Transnational Organised Crime ${ }^{39}$}

The UN Convention against Transnational Organised Crime (hereafter, the 2000 Convention) represents the response of the international community to the need for a truly global approach to the problem of transnational crime. Its purpose is to promote cooperation, both for the prevention of crime and for effective combat against it.

Like any UN instruments, it accommodates the differences and specificities of diverse legal traditions and cultures, but at the same time promoting a common language and helping to overcome some of the barriers to effective international cooperation. Specifically, the Convention: (i) defines and standardizes certain terms that are used with different meanings in different countries; (ii) requires states to establish specific offences as crimes; (iii) requires introduction of certain specific control measures, eg victims and witnesses protection; (iv) provides for the confiscation and forfeiture of proceeds of crime (ic promotes international cooperation, through extradition, joint investigations and other mutual legal assistance); (vi) provides for the extension of technical assistance in training, research and information sharing; (vii) encourages preventive policies and measures; and (vii) contains technical provisions e.g. for signature, ratification and implementation mechanisms, among others.

${ }^{35}$ Jan Wouters, et.al., op.cit. 210

${ }^{36}$ OECD, (2012), Typology on Mutual Legal Assistance in Foreign Bribery Cases, (OECD: OECD Publishing,), p.3.

${ }^{37}$ Margot Clevaland, et.al., "Trends in the International Fight against Bribery and Corruption", Journal of Business Ethics, Vol. 90, 2009, p. 212.

${ }^{38}$ Ibid. p. 212-3.

${ }^{39}$ Abdullah Y. Sahehu, "International Initiatives Against Corruption and Money Laundering: An Overvie”,' Journal of Financial Crime, Vol. 12 Issue 3, 2005, p. 226. 
For the purpose of ratification, states are required to report to the Secretary General that they have made laws and complied with a checklist which includes criminalisation of participation in an organised criminal group (Art.5); criminalisation of the laundering of proceeds of crime (Art. 6); international cooperation for the purposes of confiscation of proceeds of crime (Art. 13); extradition (Art. 16); mutual legal assistance (Art. 18); prevention (Art. 31); settlement of disputes (Art. 35); signature, ratification, acceptance, approval and accession (Art. 36); amendment (if any) (Art. 39); and denunciation (Art. 40).

\section{The United Nation Convention Against Corruption (UNCAC)}

The UNCAC ${ }^{40}$ is the first truly global anti-corruption treaty, outlining a 'common language for the anticorruption movement. It was adopted by the UN General Assembly ('UNGA') on 31 October 2003 and was opened for signature in Merida, Mexico, on 9-11 December 2003. The UNCAC entered into force two years later, on 14 December 2005. The high number of signatories and ratifications reflects the broad international consensus on the UNCAC. This consensus was not only shared among states, but also among the international private sector and civil society. ${ }^{41}$ There are 111 state parties, including the United States, which ratified it in October $2006 .^{42}$

The Convention has comprehensive chapters on concerning preventive measures, international cooperation, and mutual legal assistance. The preventive measure is predominantly phrased in non-mandatory tenus and leaves substantial scope to states parties to choose concrete implementation measures. Nevertheless, the UNCAC requires states parties to adopt measures (without imposing a detailed one-size-fits-all implementation) in a wide range of areas: they must set up anti-corruption bodies; establish appropriate procurement systems; strengthen the integrity of the judiciary; take measures to prevent private sector corruption; promote the active participation of civil society; and institute a comprehensive regulatory regime for banks and other financial institutions to prevent money laundering.

These specific provisions are preceded by the chapeau paragraph of art 5 , which requires that states parties adopt comprehensive and coordinated anti-corruption policies that promote the participation of society and reflect the principles of the rule of law, proper management of public affairs and public property, integrity, transparency and accountability.

The basic thrust of this general provision is the requirement of good governance. International cooperation also received a separate chapter in

${ }^{40}$ Came into force on 14 December 2005. So far the following ratifications or accessions have taken place: Albania, Algeria, Angola, Antigua and Barbuda, Argentina, Australia, Austria, Azerbaijan, Belarus, Benin, Bolivia, Brazil, Bulgaria, Burkina Faso, Burundi, Cameroon, Central African Republic, Chile, China, Congo, Croatia, Djibouti, Ecuador, Egypt, El Salvador, Finland, France, Honduras, Hungary, Indonesia, Jordan, Kenya, Kyrgyzstan, Latvia, Lesotho, Liberia, Libyan Arab Jamahiriya, Madagascar, Mauritius, Mexico, Mongolia, Namibia, Nicaragua, Nigeria, Norway, Panama, Paraguay, Peru, Poland, Romania, Russian Federation, Rwanda, Sao Tome and Principe, Senegal, Serbia and Montenegro, Seychelles, Sierra Leone, Slovakia, South Africa, Spain, Sri Lanka, Tajikistan, Togo, Trinidad and Tobago, Turkmenistan, Uganda, United Arab Emirates, the United Kingdom, the United Republic of Tanzania, and Yemen.

${ }^{41}$ Jan Wouters, et.al., op.cit.. p.213.

${ }^{42}$ Robert Leventhal, op.cit. p. 206. 
the UNCAC. Cooperation is mandatory for criminal matters, though for civil and administrative matters states parties need only 'consider' cooperation. Cooperation from private sector entities such as banks is only to be encouraged. This is a regrettably weak provision, as cooperation from banks and other entities is crucial in the recovery of the proceeds of corrupt acts. Requiring states parties to cooperate in criminal matters is a necessary but insufficient condition for effective asset recovery, as banks and other entities will often need to trigger prosecutions by identifying potentially corrupt transactions and notifying official authorities of such transactions. The provision on bank secrecy is more stringent: it requires states parties to ensure that bank secrecy hurdles can be overcome when conducting corruption investigations. This mandatory provision does not leave much room to manoeuvre. The same holds for art 46, which requires states parties to afford each other the widest measure of mutual legal assistance in the investigation and prosecution of offences covered by the UNCAC'

Asset recovery was a fundamental issue for developing countries during the negotiations for the UNCAC. Its importance is equally reflected in the fact that a full chapter is dedicated to this topic. Asset recovery is discussed in more detail below. It can be noted here that the chapter attempts to balance the insistence by (mostly) developing countries on effective asset recovery with procedural safeguards requested by (mostly) developed countries. The UNCAC thus aims to strike a fragile balance: on the one hand, it contains detailed and strong anti-corruption provisions, which developed countries requested; on the other hand, developing countries were willing to accept these provisions in return for strong cooperation and asset recovery provisions.

The latter were acceptable to developed countries on the condition that they were subject to sufficient procedural safeguards. Article 46 of UNCAC, entitled 'Mutual Legal Assistance', almost copies verbatim the wording of the mutual legal assistance provision in the Palermo Convention.

\section{Conclusion}

As a universal and an international phenomenon, corruption has threatened social security, democratization, good governance, and rule of law. Therefore, it is very important to govern some laws that are fight against corruption. The position of those laws is a source of international law concerning combating corruption. Some international legal instruments can be found such as OAS Convention, the OECD Anti-bribery Convention, The UN Convention against Transnational Organised Crime, and the United Nation Convention against Corruption. UNCAC is deemed as the comprehensive regulation that regulates about fighting against corruption.

\section{Bibliography}

Bhargava, Vinay, and Emil Bolongaita. (2004). Challenging Corruption in Asia: Case Studies and a Framework for Action, Washington D.C.: the World Bank.

Carr, Indira. (2007). Corruption, Legal Solutions and Limits of Law, International Journal of Law l in Context, Vol. 3 No.3 : 230-1. 
Clevaland, Margot, et.al., (2009). Trends in the International Fight against Bribery and Corruption, Journal of Business Ethics, Vol. $90: 212$.

Hess, David,. (2009). Catalyzing Corporate Commitment to Combating Corruption, Journal of Business Ethics. Vol. 88 : 781.

Johannsen, Lars and Pedersen, Karin Hilmer. (2011). For The Common Good: Combating Corruption In New EU Member States', Journal of Comparative Politics, Vol. 4 Issue 1 : 92.

Ksenia, Gerasimova, 'Can Corruption and Economic Crime be controlled in Developing Countries and if so, is it cost-effective?' (2008) Vol. 15, No.2, Journal of Financial Crime.

Konrad, Sabine, (2008).International Law and the Fight against Corruption' ASIL Proceedings : 203.

Leventhal, Robert. (2008). International Law and the Fight against Corruption, ASIL Proceedings : 204.

McCullen cited in A. Seyf, (2000), Corruption and Development, Staffordshire University : Division of Economics Working Paper N2000. : 7.

OECD. (2012). Typology on Mutual Legal Assistance in Foreign Bribery Cases, OECD: OECD Publishing. - (2011). Convention on Combating Bribery of Foreign Public Officials in International Business Transactions, OECD: OECD Publishing.

Osbourne, D., 'Corruption as Counter Culture: Attitudes to Bribery in Local and Global Society, in Rider, B.A.K. (Ed), (1997). Corruption: Enemy Within, Kluwer Law International.

Sahehu, Abdullah Y., (2005). International Initiatives against Corruption and Money Laundering: An Overview, Journal of Financial Crime, Vol. 12 Issue $3: 226$.

UNODC, 'Legislative guide for the implementation of the United Nations Convention against Corruption, 2 ${ }^{\text {nd }}$ Revised Edition 2012' <https://www.unodc.org/ documents/treaties/UNCAC/Publications/LegislativeGuide/UNCAC Legislative Guide E.pdf $>$, accessed, 19 May 2014.

World Bank, 'Helping Countries Combat Corruption: the Role of the World Bank' Poverty Reduction and Economic Management, <wwwl.worldbank.org/ publicsector/anticorrupt/orruptn/corid.html>.

Wouters, Jan., et.al. (2013). The International Legal Framework Against Corruption: Achievements And Challenges, Melbourne Journal of International Law, Vol. 14 Issue $1: 205$. 